\title{
Cinnamon effectively inhibits the activity of leukemia stem cells
}

\author{
X. Guan', M.C. Su' ${ }^{2}$, R.B. Zhao ${ }^{1}$, H.M. Ouyang ${ }^{3}$, X.D. Dong ${ }^{4}$, P. Hu ${ }^{1}$, \\ Q. Pei ${ }^{1}$, J. Lu ${ }^{1}$, Z.F. Li ${ }^{1}$, C.R. Zhang ${ }^{1}$ and T.-H Yang ${ }^{1}$ \\ ${ }^{1}$ Department of Hematology, the First People's Hospital of Yunnan Province, \\ Kunming, China \\ ${ }^{2}$ Bifeng Technology Co., Ltd. of Guangdong Province, Zhuhai, China \\ ${ }^{3}$ Department of Clinical Laboratory, \\ The First People's Hospital of Yunnan Province, Kunming, China \\ ${ }^{4}$ Department of Obstetrics, the First People's Hospital of Yunnan Province, \\ Kunming, China \\ Corresponding author: T.-H. Yang \\ E-mail: ynanblood@aliyun.com
}

Genet. Mol. Res. 15 (3): gmr.15037662

Received September 17, 2015

Accepted December 29, 2015

Published August 18, 2016

DOI http://dx.doi.org/10.4238/gmr.15037662

\begin{abstract}
Cinnamon is the main component of Sanyangxuedai, which is one of the effective traditional Chinese medicines for treating malignancies. Leukemia is a prevalent malignant disease that Sanyangxuedai has been used to treat. Although successful in several studies, there is a lack of solid evidence as to why Sanyangxuedai has an effect on leukemia, and little is known about the underlying mechanisms. In this study, the active ingredients of cinnamon were isolated, purified, and identified. The transwell transport pool formed with the Caco- 2 cell model was used to filter the active ingredients of cinnamon by simulating the gastrointestinal barrier in vitro. Moreover, the cell morphology, cell cycle status, apoptosis status, and antigenic variation of the cell surface antigens were observed and measured in K562 cells after treatment with the active ingredients of cinnamon. Our
\end{abstract}


results showed that $50-75 \mu \mathrm{M}$ was a safe concentration of cinnamon extract for treatment of K562 cells for $72 \mathrm{~h}$. The cinnamon extract caused growth inhibition of K562 cells. Cinnamon extract seemed to arrest the cells at the G1 stage and increased the apoptosis rate significantly. Interestingly, cinnamon extract treatment upregulated the expression of erythroid and myeloid differentiation antigens and downregulated that of the megakaryocytic differentiation antigens in a dose-dependent manner. Our findings indicate that cinnamon extract from Sanyangxuedai may be effective for treating leukemia.

Key words: Cinnamon; Leukemia; K562 cells; Chinese medicine

\section{INTRODUCTION}

Leukemia is one of the common malignancies of human blood cells. Leukemia is responsible for the eighth highest fatality rate among Chinese cancer patients and the highest mortality rate among children and teenagers with cancer, and air pollutants may be related to the higher morbidity of leukemia (Redaelli et al., 2005; Liu et al., 2013; Siegel et al., 2014; Cao et al., 2015). Leukemic cells are derived from hematopoietic stem cells and demonstrate excessive proliferation, differentiation failure, and apoptosis disorder characteristics (Huang et al., 2013; Cao et al., 2015). Metastasis is one of the main features of leukemia, enhancing the difficulty of its treatment (Redaelli et al., 2005). Because leukemia cells are widely distributed in the circulatory system and can invade all tissues of the body, treatment options are very limited compared to those for patients with solid tumors (Redaelli et al., 2005). Clinical synthetic antitumor drugs can efficiently and precisely treat leukemia; however, serious side effects and drug resistance caused by long-term usage are the major shortcomings (Harrington et al., 2005; Yang et al., 2008). Thus, identifying powerful active ingredients from natural resources, including Chinese herb medicine, has become a treatment strategy for leukemia. Previous studies have demonstrated the effectiveness of using purified components of Chinese herbs for treating tumors with fewer side effects (Wu and Xuan, 2007; Gao et al., 2008).

The traditional antitumor drug Sanyangxuedai from the Dai ethnic groups of Yunnan, contains pattra leaf, cinnamon, and other Chinese medicine herbs and has demonstrated effectiveness in treating non-small cell lung cancer and leukemia (Pardal et al., 2003; Kwon et al., 2010). Cinnamon was deemed the most efficient component of the aforementioned prescription for inhibiting tumor cells, and the water-soluble component of cinnamon, methyl hydroxyl chalcone polymer (MHCP), was confirmed to be responsible for cinnamon's insulinmimetic properties (Kwon et al., 2010). Additionally, cinnamon can also halt cell proliferation by interrupting the cell cycle at the $\mathrm{G}_{2} / \mathrm{M}$ phase in leukemia and lymphoma patients (Schoene et al., 2009). This process may be regulated by inhibiting the action of certain phosphatases, and enzymes may play a crucial role in facilitating mitosis (Mosmann, 1983). According to Schoene et al. (2009), the water extract of cinnamon can promote apoptosis of tumor cells and stop the cell cycle at the $\mathrm{G}_{1}$ phase. The extract also inhibits proliferation of HL- 60 cells, and it was suggested that the antitumor effect of the extract of cinnamon is associated with the concentration and time of treatment (Assadollahi et al., 2013). Furthermore, the cinnamon water extract also demonstrated antitumor effects in cervical cancer by altering the growth kinetics of the human cervical carcinoma cell line (SiHa cells), and its antitumor mechanism 
may be attributable to the loss of mitochondrial membrane potential, which induced apoptosis, or lower expression of cervical trans-membrane receptor protein Her-2 via inhibition of the metastasis of malignant cells (Koppikar et al., 2010). The inhibitory activities on NFkappaB and AP1 were demonstrated in a mouse melanoma model, which further confirmed the plausible antitumor mechanism of cinnamon (Kwon et al., 2010). However, little is known about how the cinnamon extract reduces the activity of leukemia cells. However, deriving new drugs for treating leukemia from natural resources with fewer side effects could help improve clinical outcomes.

To achieve this objective, the active ingredients with powerful effects on leukemia were isolated and purified from cinnamon. The leukemia cell line (K562 cells) was treated with these active ingredients, which were filtered via the transwell Caco- 2 cell model. This model has been widely used to investigate new drugs in vitro because of its similar characteristics to human intestinal epithelial cells. Further, the safe concentration of cinnamon extract in addition to cell morphology, cell cycle status, apoptosis, and antigenic variation of cell surface antigens were observed and analyzed to evaluate the potential role of the ingredients isolated from cinnamon on the K562 cell line.

\section{MATERIAL AND METHODS}

\section{Isolating the active ingredients from cinnamon}

Dried powder of cinnamon $(50 \mathrm{~kg})$ was treated with $80 \% \mathrm{EtOH}(3 \times 90 \mathrm{~L})$ three times, and the residue $(7.5 \mathrm{~kg})$ was collected after removing the solvent under reducing pressure. The residue was dissolved in acetone and then filtered. The acetone solution was evaporated in a vacuum to get the acetone-soluble extract $(5.0 \mathrm{~kg})$, which was suspended in water followed by successive parting with petroleum ether and EtOAc. The water-soluble extract $(1.5 \mathrm{~kg})$ was subjected to silica gel column chromatography $(\mathrm{CC})(20 \times 120 \mathrm{~cm}, 7.5 \mathrm{~kg})$ and eluted with an isocratic of $\mathrm{CHCl}_{3}-\mathrm{MeOH}-\mathrm{H}_{2} \mathrm{O}(80: 20: 2.5,25 \mathrm{~L}, \mathrm{v} / \mathrm{v})$ to yield three fractions, A-C.

Fraction A $(3.1 \mathrm{~g})$ was submitted to RP-18 CC $(3.0 \times 3.0 \mathrm{~cm}, 80 \mathrm{~g})$ by eluting with gradient aqueous $\mathrm{MeOH}(10: 90,30: 70,50: 50,70: 30,90: 10,1 \mathrm{~L}$ each, v/v) to yield two fractions, A1 and A2. Fraction A2 $(1 \mathrm{~g})$ was subjected to MCI gel CHP 20P (MITSUBISHI gel adsorption resin) $\mathrm{CC}(2.0 \times 50 \mathrm{~cm}, 100 \mathrm{~g})$ by eluting with $\mathrm{MeOH}: \mathrm{H}_{2} \mathrm{O}(30: 70,40: 60,50: 50$, $60: 40,70: 30,80: 20,700 \mathrm{~mL}$ each, v/v) to yield three fractions, A2a-A2c. Fraction A2c (300 $\mathrm{mg}$ ) was purified by preparative thin layer chromatography (TLC) by eluting with $\mathrm{CHCl}_{3}$ : $\mathrm{MeOH}(11: 1,100 \mathrm{~mL}, \mathrm{v} / \mathrm{v})$ to yield compound A (19.7 mg).

Fraction B (155 g) was subjected to sephadex LH-20 CC (6 x $125 \mathrm{~cm}, 500 \mathrm{~g})(\mathrm{MeOH})$ to obtain two portions, B1 and B2. Fraction B1 (5.2 g) was separated by RP-18 CC (3 x $50 \mathrm{~cm}$, $200 \mathrm{~g})$ by eluting with $\mathrm{MeOH}: \mathrm{H}_{2} \mathrm{O}(10: 90,30: 70,50: 50,70: 30,90: 10,1 \mathrm{~L}$ each, $\mathrm{v} / \mathrm{v})$ to provide three portions, B1a-B1c. Fraction B1b (462 mg) was purified by preparative TLC eluting with $\mathrm{CHCl}_{3}: \mathrm{MeOH} / \mathrm{H}_{2} \mathrm{O}(3: 1: 0.05,200 \mathrm{~mL}, \mathrm{v} / \mathrm{v} / \mathrm{v})$ to obtain B $(3.9 \mathrm{mg})$. Fraction B1c $(240 \mathrm{mg})$ was

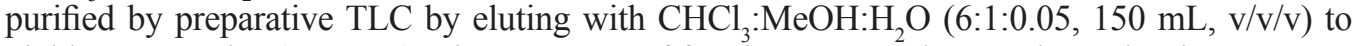
yield compound $\mathrm{C}(42.8 \mathrm{mg})$. The structures of fraction $\mathrm{A}, \mathrm{B}$, and $\mathrm{C}$ are shown in Figure 1.

\section{Cell culture}

K562 cells were obtained from Kunming Institute of Zoology, CAS. The cells were cultured with RPMI 1640 (Invitrogen, USA) supplemented with 10\% fetal bovine serum 
(FBS, Gibco, USA), 1\% (v/v) penicillin (100 U/mL, streptomycin $(100 \mathrm{U} / \mathrm{mL})$, and $1 \%(\mathrm{v} / \mathrm{v})$ l-glutamine (Invitrogen, USA). Cells were maintained at $37^{\circ} \mathrm{C}$ in $5 \% \mathrm{CO}_{2}-95 \%$ air atmosphere and sub-cultured every 3 days. All the experiments were conducted in the log phase of cell growth.

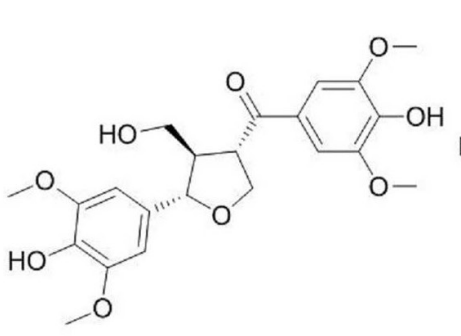

A

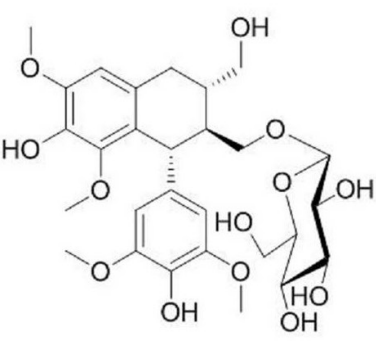

B
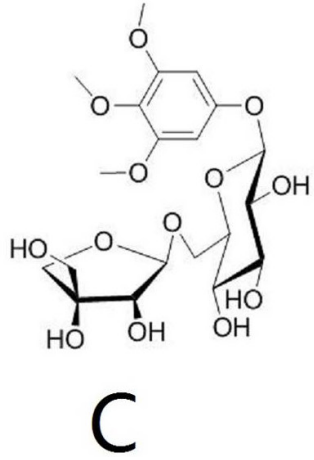

Figure 1. Structures of cinnamon extract A, B, and C. The known compounds were identified as: A. (-)-(7'S,8S, $\left.8^{\prime} R\right)-$ 4,4'-dihydroxy-3,3',5,5'-tetramethoxy-7',9-epoxylignan-9'-ol-7-one (Xiong et al., 2011); B. (-)-lyoniresinol 3 $\alpha$-O$\beta$-d-glucopyranoside (Achenbach et al., 2007); and C. 3,4,5-trimethoxyphenol $\beta$-d-apiofuranosyl (1 $\rightarrow 6$ )- $\beta$-dglucopyranoside (Shiraga et al., 1988).

\section{Transwell cell model}

To test absorption and the transport mechanism of the active ingredient from cinnamon, the transwell cell model was established with the Caco- 2 cells by simulating a gastrointestinal barrier in vitro (Yang et al., 2007). Caco-2 cells were obtained from the Kunming Institute of Zoology, CAS. Cells were cultured in cell tissue culture flasks with a $25 \mathrm{~cm}^{2}$ opening and fed twice a week with Dulbecco's modified Eagle's medium (DMEM) and the following additives: 10\% FBS, $1.5 \mathrm{~g} / \mathrm{L}$ sodium bicarbonate, $5 \mathrm{mM}$ HEPES, 50 IU penicillin, $50 \mathrm{mg} /$ $\mathrm{mL}$ streptomycin, $2 \mathrm{mM}$ glutamine, $0.1 \mathrm{mM}$ non-essential amino acids, and $100 \mathrm{mM}$ sodium pyruvate. Cell monolayers were harvested after reaching $70 \%$ confluency by using $0.25 \%$ trypsin (Sigma, USA) $/ 0.02 \%$ ethylenediaminetetraacetic acid (EDTA) solution. Cells were seeded at a density of $3.75 \times 10^{5}$ cells/well onto $3.0 \mathrm{M}$ collagen-coated six-well transwell inserts. The inserts were fed every 2 days during the duration of culturing for 21 and 28 days. The integrity of each cell monolayer was measured with an epithelial volt/ohm meter. The transepithelial electrical resistance (TEER) was measured for each cell at the monolayer over $600 \Omega / \mathrm{cm}^{2}$ to test the connection and integrity of the transwell model. Alkaline phosphatase was measured to evaluate the differentiation status of the Caco- 2 cells. Finally, the integrity of the transwell cell model was evaluated by taking electron microscope photos.

\section{Cytotoxicity assays}

To determine a safe concentration of cinnamon extract, cytotoxicity assays were performed. The Caco-2 cells were cultured on 96-well plates for $24 \mathrm{~h}$ at a density of $4 \times 10^{4}$ cells $/ \mathrm{mL}(200 \mu \mathrm{L}$ media/well). The Caco- 2 cells were exposed to 8 concentration gradients of the cinnamon extract in HBSS (Hank's Balanced Salt Solution) $(0,50,100,200,400,600$, 800 , and $1000 \mathrm{mg} / \mathrm{mL}$ ) and a control group. After incubating for $2 \mathrm{~h}, 20 \mu \mathrm{L}$ of thiazolyl blue 
tetrazolium bromide MTT solution (methylthiazolyldiphenyl tetrazolium bromide, Sigma, USA; $5 \mathrm{mg} / \mathrm{mL}$ MTT in PBS) was added to the culture medium, and cells were incubated at $37^{\circ} \mathrm{C}$ for $4 \mathrm{~h}$. The formazan crystals were dissolved by adding $150 \mu \mathrm{L}$ dimethylsulfoxide (DMSO, Sigma, USA), and the absorbance rates were measured at $490 \mathrm{~nm}$. The growth inhibitory rate was calculated using the aforementioned model. The microplate absorbance at $490 \mathrm{~nm}$ of the Caco-2 cell suspension with Hank's balanced salt solution (HBSS) alone was determined as a blank control. The microplate absorbance of the experimental groups, in which the extraction was dissolved in the Caco-2 cell suspensions with HBSS, were also measured. The concentration exhibiting more than $80 \%$ cell survival was considered non-toxic and was used in the next step.

\section{Cinnamon extract transwell transport}

To isolate the active ingredient, the cinnamon extract was filtered with Caco-2 cell monolayers in transport buffer $\left(10 \mathrm{mM}\right.$ HEPES, AMRESCO, USA) at $37^{\circ} \mathrm{C}$ (Stacker and Springer, 1991). Caco-2 cells were cultured on transwells of 6-well plates, which were used for transport after culturing for at least 21 days and less than 28 days. The cell monolayers were washed twice with HBSS to remove traces of culture media before usage. Further, the pore resistance was detected with $T>150$ by $(R s-R b) \times 4.67 \mathrm{~cm}^{2}$. The apical side buffer solution was discarded and $1.5 \mathrm{~mL}$ prepared sample liquid cinnamon extract was added (100 $\mathrm{mg} / \mathrm{mL}$ HBSS preparation, sterile) to the apical side at $37^{\circ} \mathrm{C}$ for $2 \mathrm{~h}$. Then, $2.6 \mathrm{~mL}$ of sample was taken from the basolateral side. Propranolol $(0.1 \mathrm{mM})$ or atenolol $(1 \mathrm{mM})$ was added to the transport buffer apical side. The experiment was performed in a shaker incubator at $37^{\circ} \mathrm{C}$ and 50-60 rpm for $1 \mathrm{~h}$. To detect the transshipment volume, samples from the basolateral side were collected and stored at $-20^{\circ} \mathrm{C}$ until assessed by high-performance liquid chromatography (HPLC) (Waterse2695, USA) with UV detection. The apparent permeability coefficient (Papp) was calculated (Yang et al., 2007), and the structure was measured using Papp $=\mathrm{dQ} / \mathrm{dt} \times 1 / 60$ $\mathrm{x} 1 / \mathrm{C}_{0}$. The membrane integrity test was performed before each step.

\section{HPLC}

Chromatography was carried out using $\mathrm{H}_{2} \mathrm{O}-\mathrm{CH}_{3} \mathrm{OH}$ (Sigma, USA) at $40^{\circ} \mathrm{C}$ on a 250 x $4.6 \mathrm{~mm}$ i.d., $5 \mathrm{~mm}$, Zorbax SB-C18 column. The flow rate of the mobile phase was $1 \mathrm{~mL} /$ min. The amount of cinnamon extract was $1.0 \mathrm{mg} / \mathrm{mL}$. The mobile phase A was methanol and the mobile phase B was water. The diode array detector was set to $210 \mathrm{~nm}$. Cinnamon extract samples were dissolved in a solution of $10 \mathrm{~mL}$ HBSS in a $10 \mathrm{~mL}$ cuvette. The standard cinnamon extract samples $\mathrm{A}, \mathrm{B}$, and $\mathrm{C}$ were dissolved in the mobile phase. After $0.2-\mathrm{mm}$ microporous membrane filtration, $10 \mu \mathrm{L}$ sample was analyzed by HPLC.

\section{Inhibition of K562 cell proliferation}

The K562 cells were cultured on 96-well plates at a density of $1 \times 10^{5}$ cells $/ \mathrm{mL}$ ( 200 $\mu \mathrm{L} /$ well) and exposed to 6 concentration gradients of cinnamon extract in complete medium $(5,10,25,50,75$, and $100 \mu \mathrm{M})$. After incubating for 24,48 , and $72 \mathrm{~h}$, MTT solution $(20 \mu \mathrm{L}$ $5 \mathrm{mg} / \mathrm{mL}$ MTT in PBS) was added to the culture medium and incubated at $37^{\circ} \mathrm{C}$ for $4 \mathrm{~h}$. The formazan crystals were dissolved by adding $150 \mu \mathrm{L}$ DMSO, and the absorbance rate at 490 
$\mathrm{nm}$ was measured. The growth inhibitory rate of K562 cells treated with the cinnamon extract was calculated with the following formula: (A value in the blank group minus the A value of the experimental group)/A value in the blank group $\mathrm{A} \times 100 \%$. The experiments were repeated 3 times.

\section{Effect of cinnamon extract on the K562 cells}

The K562 cells in the logarithmic growth phase were collected and the concentration of the cells was adjusted to $1 \times 10^{5}$ cells $/ \mathrm{mL}$. To test the effects of the cinnamon extracts $\mathrm{A}, \mathrm{B}$, and C, K562 cells were treated with concentrations of 50 and $75 \mu \mathrm{M}$ for $72 \mathrm{~h}$ for the experimental and control groups, repeating 3 times.

\section{Transmission electron microscopy (TEM)}

In brief, $50 \mu \mathrm{M}$ cinnamon extract from groups $\mathrm{A}, \mathrm{B}$, and $\mathrm{C}$ and the control group were fixed with $4 \%$ paraformaldehyde and $2 \%$ glutaraldehyde in $0.1 \mathrm{M}$ sodium phosphate buffer, $\mathrm{pH} 7.4$, for $4 \mathrm{~h}$ at room temperature at $25^{\circ} \mathrm{C}$. This was followed by washing the tissue pieces in $0.1 \mathrm{M}$ sodium phosphate buffer, $\mathrm{pH} 7.4$, and then placing them in $2 \%$ osmium tetroxide in 0.1 $\mathrm{M}$ sodium phosphate buffer, $\mathrm{pH} 7.4$ for $2 \mathrm{~h}$ at room temperature. Dehydration was performed in ascending gradients of ethanol, followed by embedding in Epon 812 and polymerization at $60^{\circ} \mathrm{C}$ for $48 \mathrm{~h}$. Ultrathin sections $(50-70 \mathrm{~nm})$ were obtained using an Ultracut Ultra microtome (Leica Microsystems GmbH, Wetzlar, Germany) and picked up onto 200-mesh copper grids. The sections were double stained with uranyl acetate and lead citrate and then analyzed using a FEI Tecnai-12 twin transmission electron microscope equipped with an SIS Mega View II CCD camera at $80 \mathrm{kv}$ (FEI Co., USA).

\section{Assessment of differentiation}

The K562 cells were treated with cinnamon extract A, B, and C at 50 and $75 \mu \mathrm{M}$ by continuous incubation for $72 \mathrm{~h}$ and then the cells $\left(1 \times 10^{6}\right.$ cells $\left./ \mathrm{mL}\right)$ were collected. The cells were washed with $1 \mathrm{x}$ phosphate-buffered saline (PBS) and stained with $0.5 \mathrm{~mL}(0.5 \mathrm{mg} / \mathrm{mL})$ of antibody at room temperature for $45 \mathrm{~min}$. Two-parameter analysis was performed using a FACS Calibur flow cytometer (BD FACSArial II, USA) with CELL Quest software (BD FACS Diva software, USA). The rate of the increasing percentage of cells was assessed by binding the specific antibody of mature granulocytes cell surface antigens, and the differentiation of K562 cells was determined using flow cytometry. The levels of expression of differentiation markers CD235a, CD36, CD33, CD14, CD41, CD61, CD34, and CD38 (BD, USA) were determined.

\section{Cell cycle analysis}

K562 cells $\left(1 \times 10^{6}\right.$ cells $\left./ \mathrm{mL}\right)$ in $25 \mathrm{~mL}$ medium with $10 \%$ (v/v) FBS were cultured in flasks. After incubating for $24 \mathrm{~h}$, the medium was removed and replaced with medium containing cinnamon extract $\mathrm{A}, \mathrm{B}$, and $\mathrm{C}$ at concentrations of 50 and $75 \mu \mathrm{M}$. After incubating for $72 \mathrm{~h}, \mathrm{~K} 562$ cells $\left(1 \times 10^{6}\right.$ cells $\left./ \mathrm{mL}\right)$ were collected, centrifuged at $400 \mathrm{~g}$, and washed twice with PBS. They were resuspended in $0.5 \mathrm{~mL}$ of PBS with $50 \%$ ethanol by the addition of 0.5 $\mathrm{mL}$ of ethanol dropwise. After incubating at $4^{\circ} \mathrm{C}$ for $15 \mathrm{~min}$, the cells were centrifuged and the ethanol was decanted. The cells were resuspended in $300 \mu \mathrm{L}$ of PBS with $100 \mathrm{mg} / \mathrm{mL}$ of 
RNase A and $50 \mathrm{mg} / \mathrm{mL}$ of propidium iodide for $20 \mathrm{~min}$. At $4^{\circ} \mathrm{C}$, the cells were analyzed using a FACScan machine (BD FACSArial II, USA). The data were processed using MultiCycle software (BD FACSDiva software, USA).

\section{Annexin V apoptosis analysis}

K562 cells $\left(1 \times 10^{6}\right.$ cells $\left./ \mathrm{mL}\right)$ in $25 \mathrm{~mL}$ medium with $10 \%(\mathrm{v} / \mathrm{v})$ fetal calf serum (FCS) were cultured in culture flasks and incubated for $24 \mathrm{~h}$. Then, the medium was removed and replaced with medium containing cinnamon extract A, B, and C at 50 and $75 \mu \mathrm{M}$. After incubating for $72 \mathrm{~h}, \mathrm{~K} 562$ cells $\left(1 \times 10^{6}\right.$ cells $\left./ \mathrm{mL}\right)$ were collected using gentle agitation and incubated with FITC-conjugated Annexin V. The events $(5000-10,000)$ were analyzed on a FACScan machine (BD FACSArial II, USA), and one hundred percent apoptosis was determined using Cell Quest software (BD FACSDiva software, USA).

\section{Statistical analysis}

An ANOVA was performed to estimate differences among multiple groups. The relevant statistical analysis was performed with Stata software (Version 11.0) using the twotailed test. An additional $q$ test was performed if the P value was less than 0.05 . All the data are reported as means $\pm \mathrm{SD}$.

\section{RESULTS}

\section{Stability of the reaction system}

To evaluate the effect of cinnamon extract on leukemia, the active ingredients were isolated, identified, and filtered with the Caco-2 cell monolayer model system simulating human intestinal permeability and intestinal absorption in vitro. AKP was the marker enzyme for intestinal brush border cells, which were used to test the initial differentiating biochemical characteristics of Caco-2 cells. Our results indicated that there was no AKP activity after 3 days of Caco-2 cell culture, and AKP activity was detected after 14 days of culture, indicating that this model was suitable for performing the following experiments and had the vectors and enzymes required to transfer the cinnamon extract. The integrity of the Caco- 2 cells was further validated by the observance of neat tight junctions between cells and microvilli via transmission electron microscope (Figure 2).

Propranolol and atenolol were used as drugs with high and poor absorption, respectively, and are typically used to test the stability of the Caco-2 model. The Papp values of propranolol and atenolol tested in the Caco-2 cell monolayers were $2.54 \times 10^{-5} \mathrm{~cm} / \mathrm{s}$ and $3.35 \times 10^{-7} \mathrm{~cm} / \mathrm{s}$, respectively, as determined by HPLC (Figure 3) and were comparable to the results reported in literature (Chong et al., 1997; Yee, 1997; Walle et al., 1999; Gao et al., 2001). Our results indicated that the Caco-2 model could be used to evaluate the transport of cinnamon extract. 

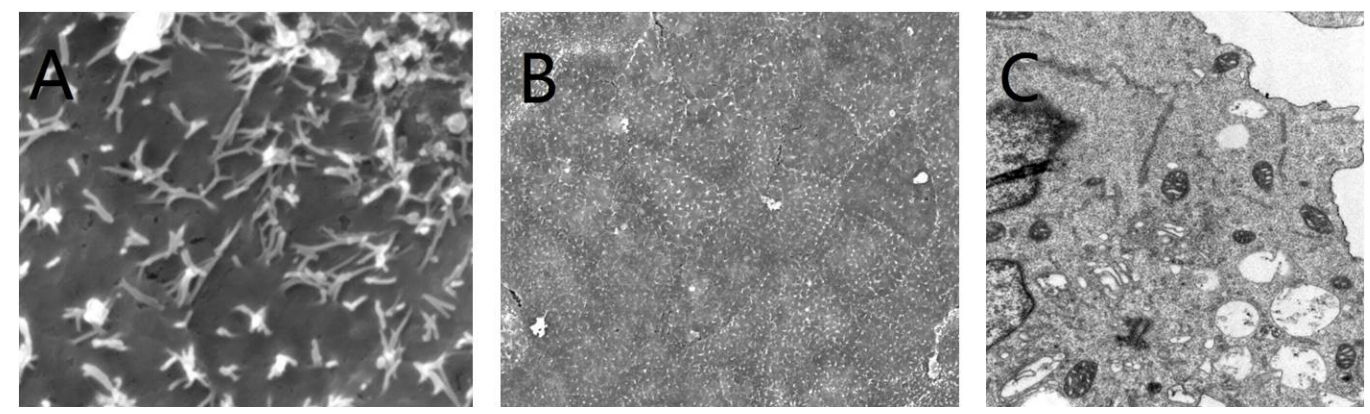

Figure 2. Characteristic microvilli of apical side of the differentiated Caco-2 monolayer. A. Scanning electron micrograph, 15,000X. B. Scanning electron micrograph, 3000X. C. Transmission electron micrograph, 20,000X.
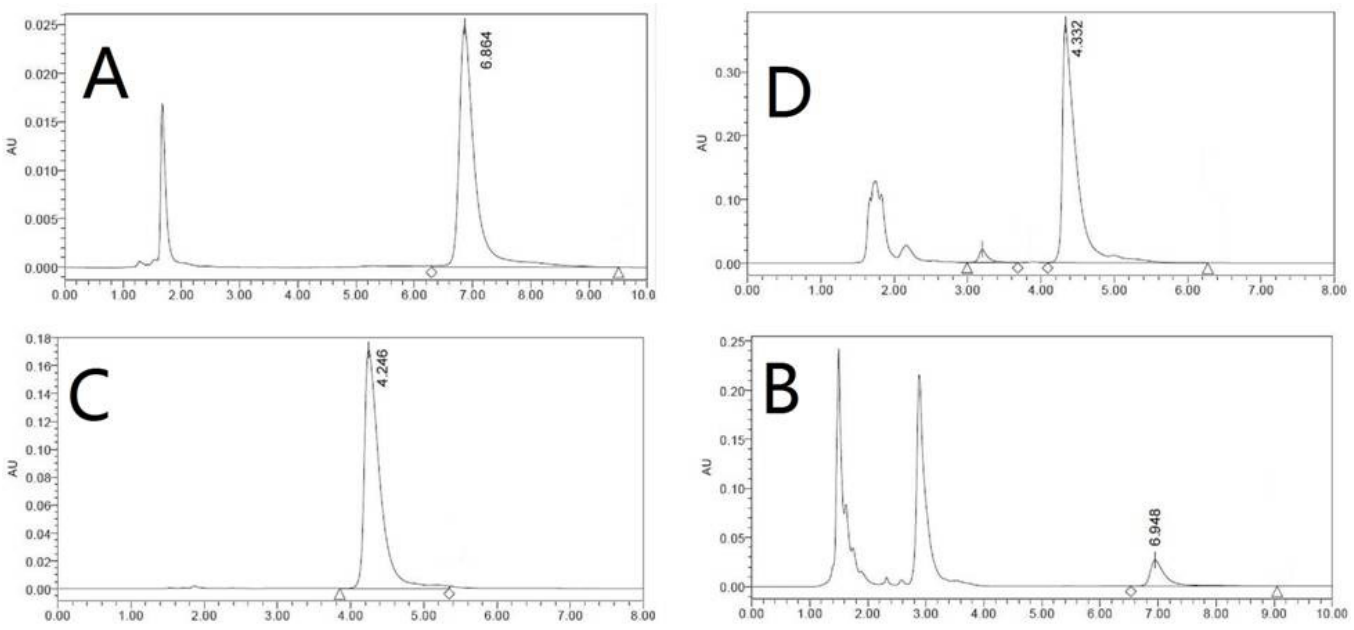

Figure 3. HPLC profile of propranolol and atenolol. A. Propranolol standard. B. Propranolol absorbed by transwell. C. Atenolol standard. D. Atenolol absorbed by transwell.

\section{Cell toxicity}

The inhibition rate of Caco-2 cells increased with increasing concentration of cinnamon extract after $200 \mathrm{mg} / \mathrm{mL}$ (Table 1). The survival rate of the Caco-2 cells was less than $58.35 \%$. However, the inhibition rate of cinnamon extract was less than $20 \%$ at concentrations less than $100 \mathrm{mg} / \mathrm{mL}$, which was not significantly different from the negative control group. Thus, a concentration of $100 \mathrm{mg} / \mathrm{mL}$ was used in the non-cytotoxic cell membrane experiments.

\section{HPLC}

Cinnamon extract A, B, and C were dissolved in HBSS, and filtered with the Caco-2 cell model in vitro for $2 \mathrm{~h}$. The absorbents from the basolateral side were collected, and were identified using HPLC (Figure 4), the nuclear magnetic resonance hydrogen spectrum, and the carbon spectrum (Figure 5). The mobile phase conditions are specified in Table 2. 
Table 1. Cinnamon cytotoxicity $(\mathrm{N}=3$, means $\pm \mathrm{SD}, \%)$.

\begin{tabular}{|c|c|c|c|c|}
\hline Groups & Concentration $(\mu \mathrm{g} / \mathrm{mL})$ & Cell survival rate (\%) & $F, \mathrm{P}$ & $\mathrm{P}$ \\
\hline Control & 0 & $88.12 \pm 16.26$ & \multirow[t]{8}{*}{$1542.78,0.0001$} & \\
\hline \multirow[t]{7}{*}{ Cinnamon } & 50 & $82.48 \pm 12.14$ & & 0.151 \\
\hline & 100 & $81.56 \pm 14.21$ & & 0.014 \\
\hline & 200 & $58.35 \pm 13.36$ & & $0.001^{\mathrm{a}}$ \\
\hline & 400 & $25.14 \pm 15.19$ & & $0.001^{\mathrm{a}}$ \\
\hline & 600 & $23.79 \pm 10.22$ & & $0.001^{\mathrm{a}}$ \\
\hline & 800 & $10.25 \pm 11.54$ & & $0.001^{\mathrm{a}}$ \\
\hline & 1000 & $10.65 \pm 10.84$ & & $0.001^{\mathrm{a}}$ \\
\hline
\end{tabular}

$\mathrm{P}=$ compared with control. ${ }^{\text {aP }}$ value is less than 0.001 .

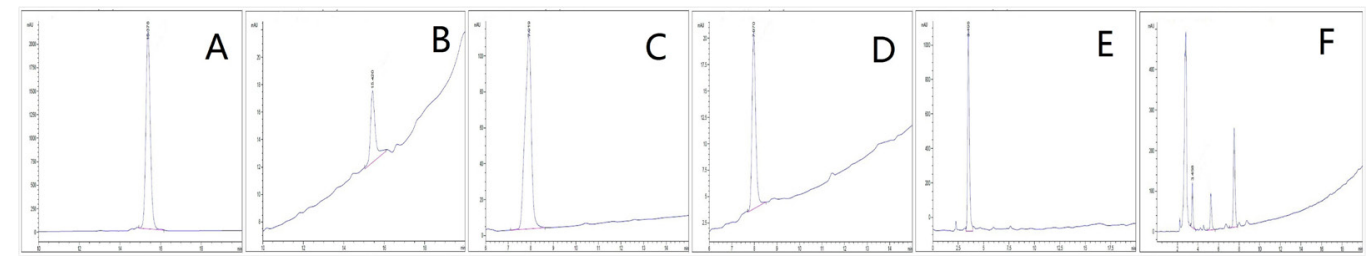

Figure 4. HPLC profile of cinnamon. A. Cinnamon extract A. B. Cinnamon extract A after going through the monomer absorption model. C. Cinnamon extract B. D. Cinnamon extract B after going through the monomer absorption model. E. Cinnamon extract C. F. Cinnamon extract $\mathrm{C}$ after going through the monomer absorption model; Cinnamon extract A, $\mathrm{t}=15.378 \mathrm{~s}$, through the monomer absorption model, $\mathrm{t}=15.420 \mathrm{~s}$. Cinnamon extract $\mathrm{B}, \mathrm{t}=7.919 \mathrm{~s}$, through the monomer absorption model, $\mathrm{t}=7.970 \mathrm{~s}$. Cinnamon extract $\mathrm{C}, \mathrm{t}=3.495 \mathrm{~s}$, through the monomer absorption model, $\mathrm{t}=3.458 \mathrm{~s}$.

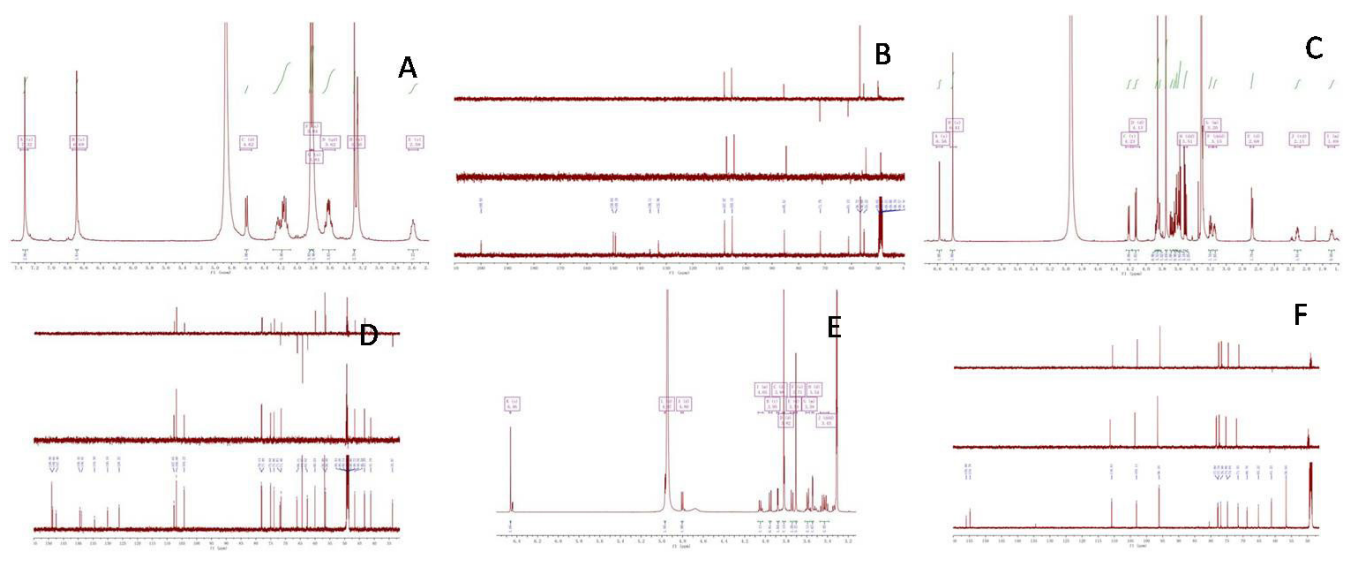

Figure 5. Hydrogen and carbon spectrums of cinnamon extract. A. The hydrogen spectrum of cinnamon extract A. B. The carbon spectrum of cinnamon extract A. C. The hydrogen spectrum of cinnamon extract B. D. The carbon spectrum of cinnamon extract B. E. The hydrogen spectrum of cinnamon extract C. F. The carbon spectrum of cinnamon extract $\mathrm{C}$.

Table 2. Mobile phase of cinnamon extract.

\begin{tabular}{l|c|c|c|c|c|c|c|c}
\hline \multicolumn{3}{c|}{ Mobile phase of cinnamon extract A } & \multicolumn{3}{c|}{ Mobile phase of cinnamon extract B } & \multicolumn{3}{c}{ Mobile phase of cinnamon extract C } \\
\hline $\begin{array}{l}\text { Time } \\
(\mathrm{min})\end{array}$ & $\begin{array}{c}\text { Mobile phase A } \\
(\%)\end{array}$ & $\begin{array}{c}\text { Mobile phase B } \\
(\%)\end{array}$ & $\begin{array}{c}\text { Time } \\
(\mathrm{min})\end{array}$ & $\begin{array}{c}\text { Mobile phase A } \\
(\%)\end{array}$ & $\begin{array}{c}\text { Mobile phase B } \\
(\%)\end{array}$ & $\begin{array}{c}\text { Time } \\
(\mathrm{min})\end{array}$ & $\begin{array}{c}\text { Mobile phase A } \\
(\%)\end{array}$ & $\begin{array}{c}\text { Mobile phase B } \\
(\%)\end{array}$ \\
\hline $0-20$ & $28 \rightarrow 50$ & $72 \rightarrow 50$ & $0-17$ & $28 \rightarrow 50$ & $72 \rightarrow 50$ & $0-17$ & $28 \rightarrow 50$ & $72 \rightarrow 50$ \\
\hline $20-35$ & $50 \rightarrow 80$ & $50 \rightarrow 20$ & $17-20$ & $50 \rightarrow 28$ & $50 \rightarrow 72$ & $17-20$ & $50 \rightarrow 28$ & $50 \rightarrow 72$ \\
\hline $35-40$ & $80 \rightarrow 28$ & $20 \rightarrow 72$ & & & & & & \\
\hline
\end{tabular}




\section{Proliferation}

To determine the optimal concentration of cinnamon extract for K562 cells, a cytotoxicity test was performed. As shown in Figure 6, our results indicated that cinnamon extract could significantly inhibit the proliferation of K562 cells after prolonged treatment. In addition, increasing doses of extraction $\mathrm{A}, \mathrm{B}$, and $\mathrm{C}$ increased the inhibition of proliferation of K562 cells at 24, 48, and $72 \mathrm{~h}$. Our results indicated that the proliferation of K562 cells could be inhibited by treatment with cinnamon extract A, B, and C at doses of 50-75 $\mu \mathrm{M}$ for $72 \mathrm{~h}$ (Figure 6).
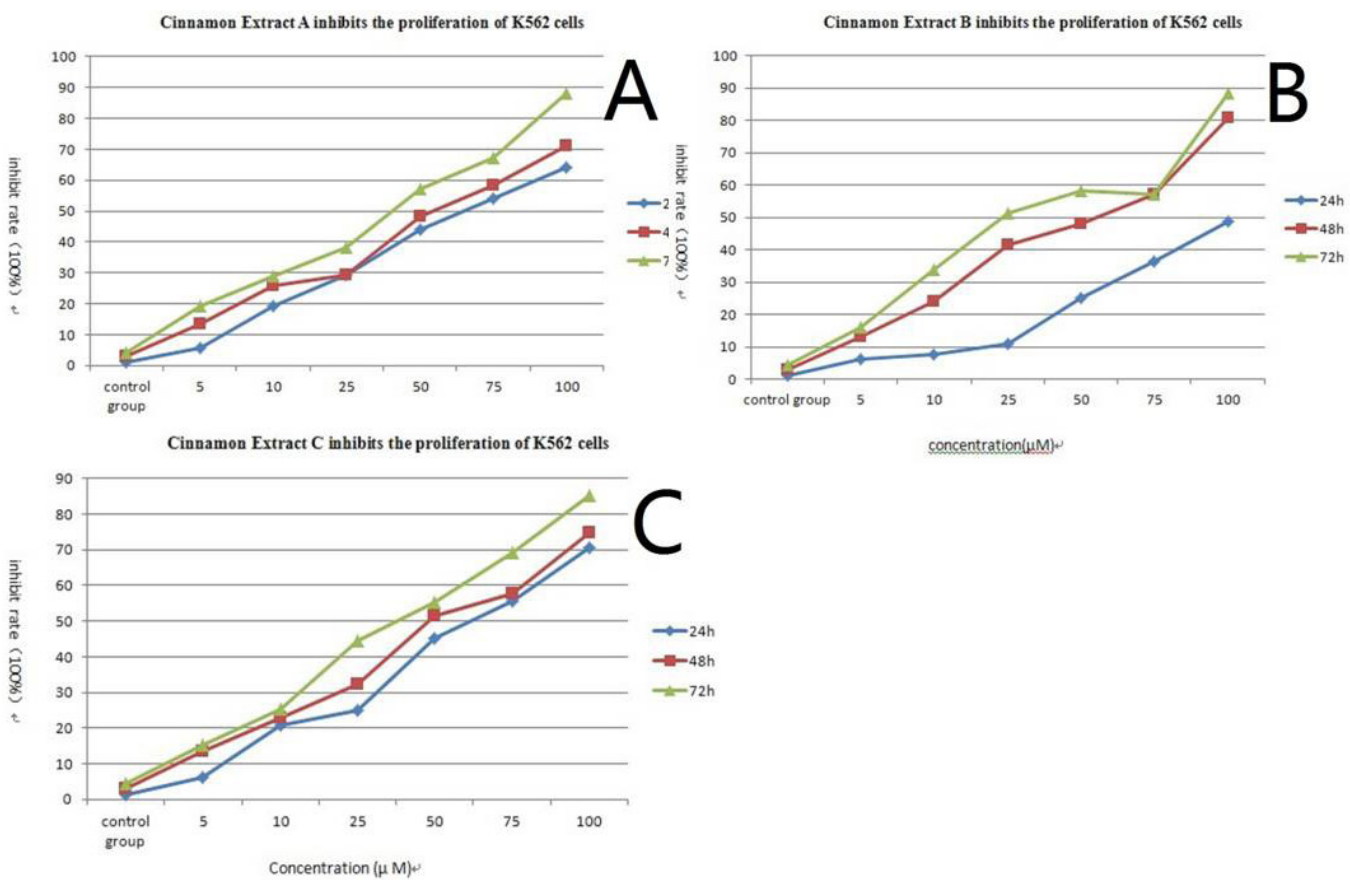

Figure 6. Cinnamon extract inhibits the proliferation of K562 cells. A. Cinnamon extract A. B. Cinnamon extract B. C. Cinnamon extract C; P $<0.05$, compared with control.

\section{Morphological changes in K562 cells}

To verify whether cinnamon extract A, B, and C can affect the cell morphology of K562 cells, cells in the control and treatment groups were observed with an electron microscope. Our results indicated that untreated K562 cells grew well, had clear cytoskeletons, a defined circular shape, and pronounced nucleoli (Figure 7A). The groups treated with $50 \mu \mathrm{M}$ cinnamon extract for $72 \mathrm{~h}$ had pyknotic nuclei, agglutinated chromatin, distorted nuclear membranes, cavities of the cytoplasm, and an increasing electronic concentration in the cytoplasm compared with the control group (Figure 7B, C, and D). 


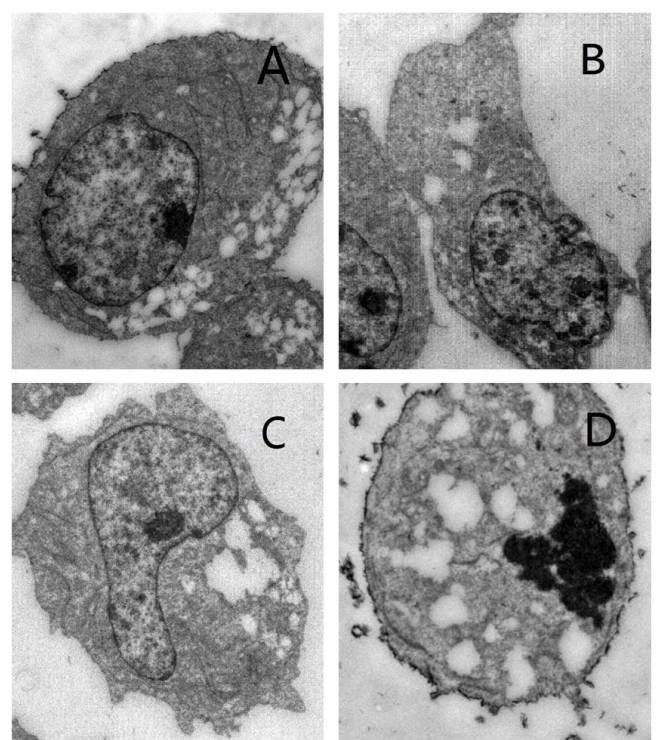

Figure 7. Morphological changes induced by cinnamon extract in K562 cells (8000X). K562 cells were seeded in culture bottles without cinnamon extract (A) and with $50 \mu \mathrm{M}$ cinnamon extract (B, C, and D) for $72 \mathrm{~h}$. Apoptotic cells (in B, C, and D) were characterized by transmission electron microscope (8000X).

\section{$\mathrm{G}_{1}$ arrest}

To further illustrate the potential role cinnamon extract A, B, and C on the K562 cell lines, the cell cycle was examined for control and treatment groups. The induction of apoptosis in cinnamon extract-treated cells was further verified by flow cytometric analysis of DNA content. Loss of DNA is a typical feature of apoptotic cells. In the present study, K562 cells treated with cinnamon extract $(50$ and $75 \mu \mathrm{M})$ for $72 \mathrm{~h}$ were analyzed using FACS. Table 3 illustrates the DNA content histograms obtained after PI (propidium iodide) staining of permeabilized cells. In agreement with DNA fragmentation results, typical sub-diploid apoptotic peaks were observed in K562 cells treated with cinnamon extract for $72 \mathrm{~h}$. The FACS analysis of control cells, on the other hand, showed prominent $\mathrm{G}_{1}$, followed by the $\mathrm{S}$ phase (Figure 8). Flow cytometric analysis of cinnamon extract-treated cells showed an increase in hypodiploid apoptotic cells in a concentration-dependent manner, a decrease in cells in the $S$ phase, and an increase of cells in the $G_{1}$ phase of the cell cycle. This suggests that cinnamon extract-induced apoptosis occurs during the $\mathrm{G}_{1}$ phase of the cell cycle.

The effect of cinnamon extract A was examined in K562 cells at $72 \mathrm{~h}$ with concentrations of 50 and $75 \mu \mathrm{M}$, and the rates of cells in the G1 stage were 58.176 and $61.376 \%$, respectively. The proportion of cells in the S phase was 41.824 and $38.624 \%$ at 50 and $75 \mu \mathrm{M}$, respectively. The percentage of cells in the G1 stage was increased compared to the control group (54.192\%), and the rate of cells in the S stage decreased to $45.086 \%$ of the control group. This pattern was similar to that of cells in the cinnamon extract B treatment group. Cells in the cinnamon extract B group exhibited percentages of cells in the G1 phase of 56.519 and $60.526 \%$ after treatment with 50 and $75 \mu \mathrm{M}$, respectively, and the proportions of cells in the S phase were 43.481 and $39.474 \%$. Interestingly, in the cinnamon extract C 
group, the G1 phase cells accounted for 59.264 and $61.047 \%$, at 50 and $75 \mu \mathrm{M}$, respectively, and the percentages of cells in the S phase were 40.736 and $38.953 \%$. Our results indicated that cinnamon extract A, B, and C can increase the percentage of leukemia cells (K562) in the G1 stage and decrease the percentage of cells in the S phase. The percentage of cells in the G1 phase increased with increasing concentration of cinnamon extract.

Table 3. Effects of cinnamon extract A, B, and C on the cycle of $\mathrm{K} 562$ cells after treatment for $72 \mathrm{~h}$.

\begin{tabular}{l|c|c|c|c|c|c}
\hline & A G1 stage & A S stage & B G1 stage & B S stage & C G1 stage & C S stage \\
\hline $50 \mu \mathrm{M}$ & $58.176 \pm 0.212$ & $41.824 \pm 0.246$ & $56.519 \pm 0.114$ & $43.481 \pm 0.505$ & $59.264 \pm 0.221$ & $40.736 \pm 0.335$ \\
\hline $75 \mu \mathrm{M}$ & $61.376 \pm 0.905$ & $38.624 \pm 0.283$ & $60.526 \pm 0.277$ & $39.474 \pm 0.103$ & $61.047 \pm 0.325$ & $38.953 \pm 0.752$ \\
\hline Control & $54.192 \pm 0.147$ & $45.086 \pm 0.255$ & & & & \\
\hline
\end{tabular}

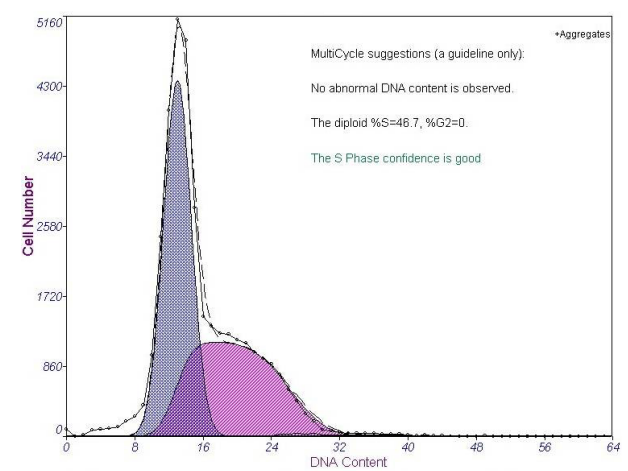

Figure 8. Analysis of cell cycle distribution method and DNA content in each phase of $\mathrm{G}_{1}$ and $\mathrm{S}$ in the $\mathrm{K} 562$ cell line.

\section{Apoptosis}

After exposing the K562 cells to 50 and $75 \mu \mathrm{M}$ cinnamon extract A, B, and C for $72 \mathrm{~h}$, cell apoptosis was evaluated using flow cytometry, and the results are shown in Table 4 . In the cells exposed to extract A, we found that the apoptosis rates at the G1 stage were 12.73 and $23.65 \%$, which were significantly different from the control group at $5.81 \%(\mathrm{P}<0.01)$. For cinnamon extract $\mathrm{B}$ and $\mathrm{C}$ the apoptosis rates were 14.28 and $22.77 \% *$ for extract $\mathrm{B}$ and 20.44 and $35.38 \% *$ for extract $C$, which were also significantly different from the control group (Figure 9) (Table 4). Our results showed that cinnamon extract A, B, and C can increase apoptosis of K562 cells.

\section{K562 cell differentiation antigen detection}

To further confirm the ability of cinnamon extract to induce the differentiation of K562 cells, the terminal differentiation surface antigens of myeloid, erythroid, megakaryocyte, and the stem cell differentiation phenotype were tested. We found that myeloid differentiation phenotypes (CD13, CD33, and CD36), erythroid differentiation phenotype (CD235a), megakaryocyte differentiation phenotypes (CD41, CD61), and stem cell differentiation phenotypes (CD34, CD38) were all changed compared to the control group (Figure 10). Specifically, myeloid and erythroid differentiation phenotypes were increased (CD36, CD13, CD33, and CD235a) and megakaryocyte differentiation phenotypes were decreased (CD41 and CD61) in K562 cells (Table 5). There were no significant changes in stem cell differentiation. 
Table 4. Cinnamon extract induces apoptosis of K562 cells after $72 \mathrm{~h}$ (FCM).

\begin{tabular}{l|c|c|c|c}
\hline Group & Concentration $(\mu \mathrm{M})$ & Apoptosis $(\%)$ & $F, \mathrm{P}$ & $\mathrm{P}$ \\
\hline Control & 0 & $5.81 \pm 1.12$ & \multirow{2}{*}{$79.67,0.0001$} & \\
\hline Cinnamon extract A & 50 & $12.73 \pm 0.95$ & & 0.024 \\
\cline { 2 - 3 } & 75 & $23.65 \pm 1.05$ & & $0.001^{\mathrm{a}}$ \\
\hline Cinnamon extract B & 50 & $14.28 \pm 1.39$ & & 0.005 \\
\cline { 2 - 3 } & 75 & $22.77 \pm 4.24$ & & $0.001^{\mathrm{a}}$ \\
\cline { 2 - 3 } & 50 & $20.44 \pm 0.40$ & & $0.001^{\mathrm{a}}$ \\
\cline { 2 - 3 } & 75 & $35.38 \pm 0.68$ & & $0.001^{\mathrm{a}}$ \\
\hline
\end{tabular}

$\mathrm{P}=$ compared with control. ${ }^{\text {PP }}$ value is less than 0.001 .
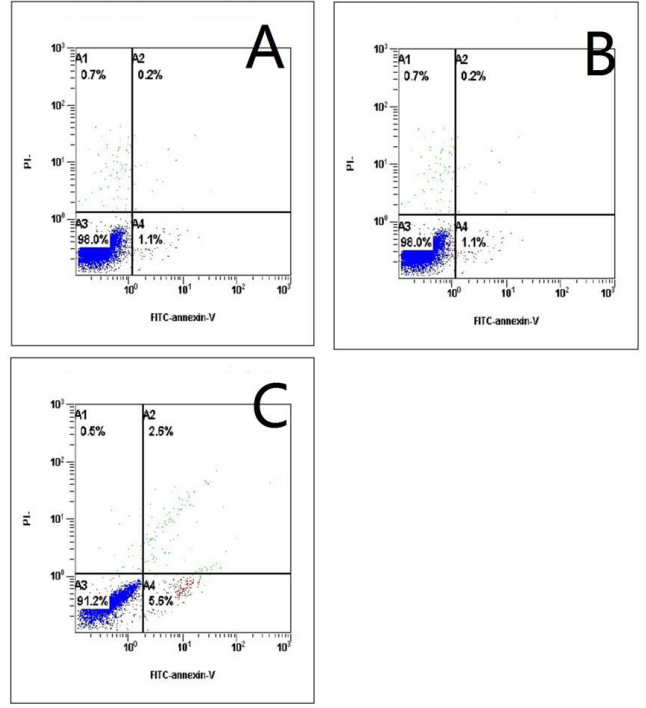

Figure 9. Effects of 50 and $75 \mu \mathrm{M}$ cinnamon extract on the apoptosis of K562 cells treated for $72 \mathrm{~h}$.

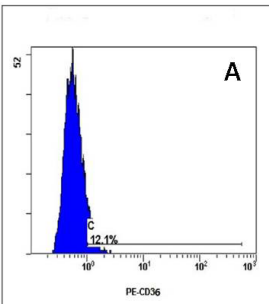

PE.CD36
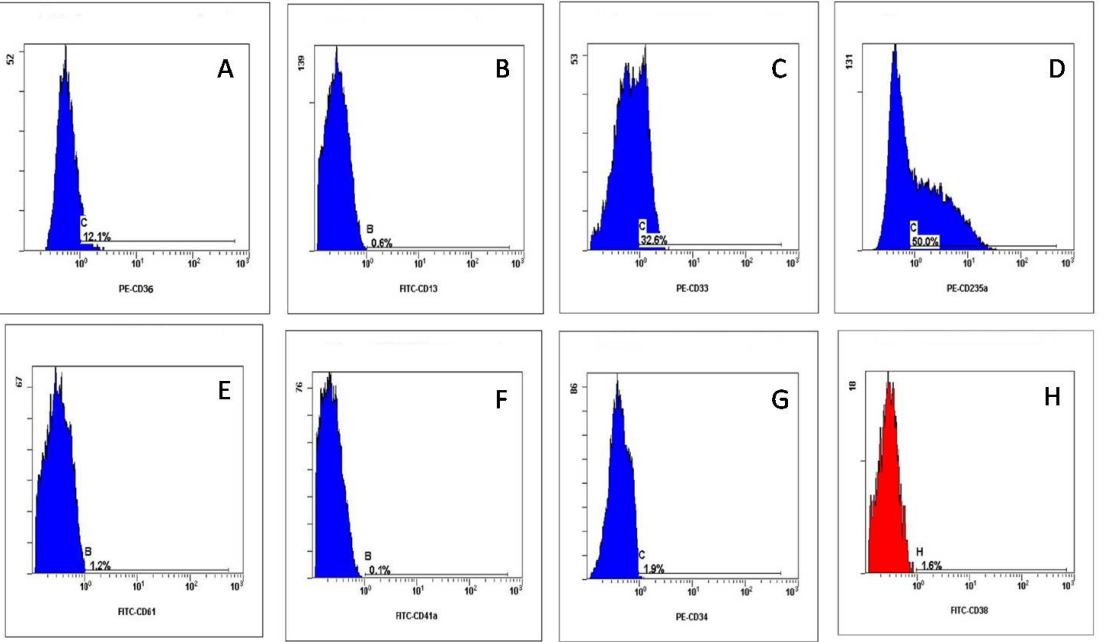

Figure 10. Differentiation antigens of K562 cells. A. PE-CD36. B. FITC-CD13. C. FITC-CD33. D. PE-CD235a. E. FITC-CD61. F. PE-CD41. G. PE-CD34. H. FITC-CD38. 


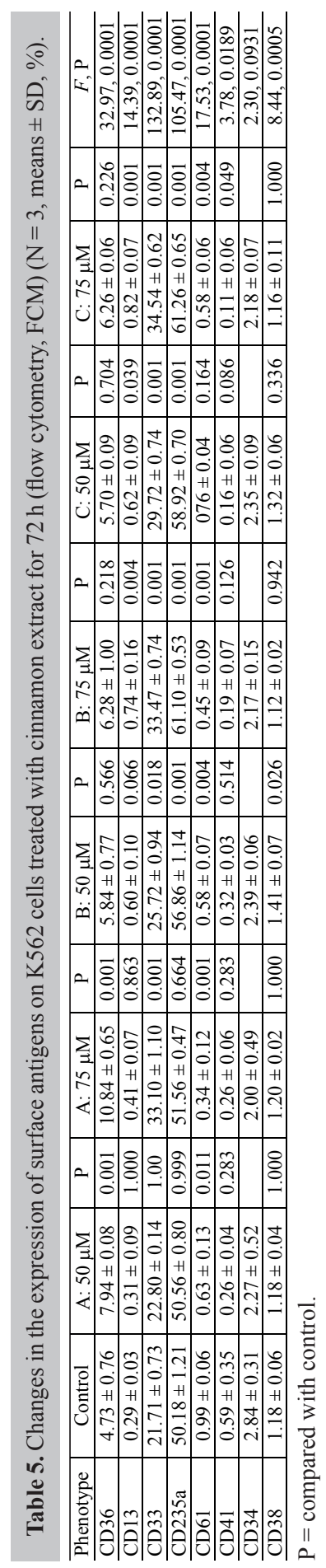




\section{DISCUSSION}

Leukemia is one of the common malignancies of blood cells. Excessive proliferation, differentiation failure, and apoptosis disorder characteristics are the major features of leukemia, which requires different treatment measures than those needed for solid tumors. Previous studies have shown that the traditional anti-tumor herb Sanyangxuedai from the Dai ethnic groups of Yunnan has a powerful therapeutic effect against non-small cell lung cancer and leukemia (Pardal et al., 2003). In the present study, we demonstrated that Sanyangxuedai, a traditional Chinese medicine that has effectively been used to treat non-small cell lung cancer and leukemia, predominately inhibits cell growth in the leukemia cell line (K562) by arresting the cells in the G1 stage.

Three new active ingredients of cinnamon, the main components of Sanyangxuedai, were isolated. To purify these active ingredients, which can be absorbed by K562 cells, they were filtered using the transwell Caco-2 cell model, which has been widely used to investigate new drugs because of its similar characteristics to human intestinal epithelial cells in vitro (Hidalgo et al., 1989). Our results showed that 50-75 $\mu \mathrm{M}$ was a suitable concentration range for the three active ingredients of cinnamon for $72 \mathrm{~h}$ (Figure 6). Because apoptosis induction is considered to be the primary function of drugs that are effective against many types of cancer (Nicholson, 2000; Fesik, 2005), the proliferation and morphology of K562 cells were observed after exposure to the active ingredients (A, B, and C) of cinnamon. We found that these ingredients could inhibit the proliferation of K562 cells in vitro at concentrations of 50$75 \mu \mathrm{M}$ after $72 \mathrm{~h}$ (Figure 6). After $72 \mathrm{~h}$ of exposure, the morphological changes in K562 cells were screened with an electron microscope (Figure 7A, B, C, and D). The pyknotic nuclei, agglutinated chromatin, distorted nuclear membrane, and cavity of the cytoplasm of the K562 cells were detected, which supported our apoptosis findings. Furthermore, the cell cycles were verified by flow cytometric analysis of DNA content, and our results indicated higher rates of cells in the G1 stage and a decreased number of cells in the S phase (Figure 8), in agreement with previous findings (Schoene et al., 2005). Previous studies have shown that the expression of antigen markers for the cell membrane, plasma, and nuclei were closely related with the cell stage during the differentiation process of hematopoietic cells, and can serve as effective biomarkers for cell cycles (Sugimoto et al., 1989). Specific antigen expression was taken as the characteristic marker to distinguish the cell cycle in leukemia cells (Kaleem et al., 2003). In this study, our data showed that the expression of erythroid differentiation antigen CD235a of K562 cells increased after exposure to cinnamon extract for $72 \mathrm{~h}$, and this effect was dose-dependent. The expression of myeloid differentiation antigens CD36, CD13, and CD33 showed a similar pattern to that of erythroid differentiation antigens. K562 cells have ancentrial initial features and have the potential to differentiate into other myeloid cells. However, the expression of biomarkers of progenitor cells, such as CD34 and CD38, were only 2.12 and $1.21 \%$, respectively, after exposure for $72 \mathrm{~h}$. The heterogenic characteristics of leukemia cells may cause the aforementioned phenotypes. The expression of megakaryocytic differentiation antigens CD61 and CD41 did not change.

In summary, we found that cinnamon, which forms the crucial components of Sanyangxuedai, an effective antitumor herb, could inhibit cell apoptosis by arresting cells at the G1 stage. This corresponded to an up-regulation in the expression of erythroid and myeloid differentiation antigens and down-regulation of the expression of megakaryocytic differentiation antigens with dose-dependence. Our findings revealed that cinnamon extract might be useful for treating leukemia. 


\section{Conflicts of interest}

The authors declare no conflict of interest.

\section{ACKNOWLEDGMENTS}

We thank the anonymous reviewers for their helpful comments on the manuscript. Research supported by the National Natural Science Foundation of China (Grant \#81160483).

\section{REFERENCES}

Achenbach H, Löwel M, Waibel R, Gupta M, et al. (2007). New lignan glucosides from Stemmadenia minima. Planta Med. 58: 270-272.

Assadollahi V, Parivar K, Roudbari NH, Khalatbary AR, et al. (2013). The effect of aqueous cinnamon extract on the apoptotic process in acute myeloid leukemia HL-60 cells. Adv. Biomed. Res. 2: 25. http://dx.doi.org/10.4103/22779175.108001

Cao S, Yang G, Zhang J, Shen Y, et al. (2015). Replication analysis confirms the association of several variants with acute myeloid leukemia in Chinese population. J. Cancer Res. Clin. Oncol. 10.1007/s00432-015-2010-6.

Chong S, Dando SA and Morrison RA (1997). Evaluation of Biocoat intestinal epithelium differentiation environment (3day cultured Caco-2 cells) as an absorption screening model with improved productivity. Pharm. Res. 14: 1835-1837. http://dx.doi.org/10.1023/A:1012112820371

Fesik SW (2005). Promoting apoptosis as a strategy for cancer drug discovery. Nat. Rev. Cancer 5: 876-885. http://dx.doi. org $/ 10.1038 / \mathrm{nrc1736}$

Gao J, Hugger EE, Beck-Westermeyer MS and Borchardt RT (2001). Estimating intestinal mucosal permeation of compounds using Caco-2 cell monolayers. Curr. Protoc. Pharmacol. Chapter 7: Unit 7.2.

Gao JL, Shi JM, He K, Zhang QW, et al. (2008). Yanhusuo extract inhibits metastasis of breast cancer cells by modulating mitogen-activated protein kinase signaling pathways. Oncol. Rep. 20: 819-824.

Harrington KJ, Nutting CM and Pandha HS (2005). Gene therapy for head and neck cancer. Cancer Metastasis Rev. 24: 147-164.http://dx.doi.org/10.1007/s10555-005-5053-3

Hidalgo IJ, Raub TJ and Borchardt RT (1989). Characterization of the human colon carcinoma cell line (Caco-2) as a model system for intestinal epithelial permeability. Gastroenterology 96: 736-749.

Huang X, Ma D, Dong W, Li P, et al. (2013). Gene expression profiling of the DNMT3A R882 mutation in acute leukemia. Oncol. Lett. 6: 268-274.

Kaleem Z, Crawford E, Pathan MH, Jasper L, et al. (2003). Flow cytometric analysis of acute leukemias. Diagnostic utility and critical analysis of data. Arch. Pathol. Lab. Med. 127: 42-48.

Koppikar SJ, Choudhari AS, Suryavanshi SA, Kumari S, et al. (2010). Aqueous cinnamon extract (ACE-c) from the bark of Cinnamomum cassia causes apoptosis in human cervical cancer cell line ( $\mathrm{SiHa}$ ) through loss of mitochondrial membrane potential. BMC Cancer 10: 210. http://dx.doi.org/10.1186/1471-2407-10-210

Kwon HK, Hwang JS, So JS, Lee CG, et al. (2010). Cinnamon extract induces tumor cell death through inhibition of NFkappaB and AP1. BMC Cancer 10: 392. http://dx.doi.org/10.1186/1471-2407-10-392

Liu YQ, Zhao FJ, Chen WQ, Chen LL, et al. (2013). An analysis of incidence and mortality of leukemia in China, 2009. China Cancer 22: 528-534.

Mosmann T (1983). Rapid colorimetric assay for cellular growth and survival: application to proliferation and cytotoxicity assays. J. Immunol. Methods 65: 55-63. http://dx.doi.org/10.1016/0022-1759(83)90303-4

Nicholson DW (2000). From bench to clinic with apoptosis-based therapeutic agents. Nature 407: 810-816. http://dx.doi. org $/ 10.1038 / 35037747$

Pardal R, Clarke MF and Morrison SJ (2003). Applying the principles of stem-cell biology to cancer. Nat. Rev. Cancer 3: 895-902. http://dx.doi.org/10.1038/nrc1232

Redaelli A, Laskin BL, Stephens JM, Botteman MF, et al. (2005). A systematic literature review of the clinical and epidemiological burden of acute lymphoblastic leukaemia (ALL). Eur. J. Cancer Care (Engl.) 14: 53-62. http:// dx.doi.org/10.1111/j.1365-2354.2005.00513.x

Schoene NW, Kelly MA, Polansky MM and Anderson RA (2005). Water-soluble polymeric polyphenols from cinnamon inhibit proliferation and alter cell cycle distribution patterns of hematologic tumor cell lines. Cancer Lett. 230: 134140. http://dx.doi.org/10.1016/j.canlet.2004.12.039 
Schoene NW, Kelly MA, Polansky MM and Anderson RA (2009). A polyphenol mixture from cinnamon targets p38 MAP kinase-regulated signaling pathways to produce G2/M arrest. J. Nutr. Biochem. 20: 614-620. http://dx.doi. org/10.1016/j.jnutbio.2008.06.006

Shiraga Y, Okano K, Akira T, Fukaya C, et al. (1988). Structures of potent antiulcerogenic compounds from Cinnamomum cassia. Tetrahedron 44: 4703-4711.

Siegel R, Ma J, Zou Z and Jemal A (2014). Cancer statistics, 2014. CA Cancer J. Clin. 64: 9-29. http://dx.doi.org/10.3322/ caac. 21208

Stacker SA and Springer TA (1991). Leukocyte integrin P150,95 (CD11c/CD18) functions as an adhesion molecule binding to a counter-receptor on stimulated endothelium. J. Immunol. 146: 648-655.

Sugimoto T, Horii Y, Hino T, Kemshead JT, et al. (1989). Differential susceptibility of HLA class II antigens induced by gamma-interferon in human neuroblastoma cell lines. Cancer Res. 49: 1824-1828.

Walle UK, French KL, Walgren RA and Walle T (1999). Transport of genistein-7-glucoside by human intestinal CACO-2 cells: potential role for MRP2. Res. Commun. Mol. Pathol. Pharmacol. 103: 45-56.

Wu B and Xuan ZR (2007). Progress in research on applying Sijunzi Decoction in treating digestive malignant tumor. Chin. J. Integr. Med. 13: 156-159.http://dx.doi.org/10.1007/s11655-007-0156-Z

Xiong L, Zhu C, Li Y, Tian Y, et al. (2011). Lignans and neolignans from Sinocala musaffinis and their absolute configurations. J. Nat. Prod. 74: 1188-1200.

Yang XW, Yang XD, Wang Y, Ma L, et al. (2007). Establishment of Caco-2 cell monolayer model and standard operation procedure for assessing intestinal absorption of chemical components of traditional Chinese medicine. Zhong Xi Yi Jie He Xue Bao 5: 634-641. http://dx.doi.org/10.3736/jcim20070607

Yang YF, Ge JZ, Wu Y, Xu Y, et al. (2008). Cohort study on the effect of a combined treatment of traditional Chinese medicine and Western medicine on the relapse and metastasis of 222 patients with stage II and III colorectal cancer after radical operation. Chin. J. Integr. Med. 14: 251-256. http://dx.doi.org/10.1007/s11655-008-0251-9

Yee S (1997). In vitro permeability across Caco-2 cells (colonic) can predict in vivo (small intestinal) absorption in manfact or myth. Pharm. Res. 14: 763-766. http://dx.doi.org/10.1023/A:1012102522787 